\title{
A Selfie with Two Books on Humanism and Ideology
}

Author(s): Martha Bohachevsky-Chomiak

Source: Kyiv-Mohyla Humanities Journal 3 (2016): 215-221

Published by: National University of Kyiv-Mohyla Academy

http://kmhj.ukma.edu.ua/ 


\title{
A Selfie with Two Books on Humanism and Ideology
}

\author{
Martha Bohachevsky-Chomiak
}

(2)

The editor of the Kyiv-Mohyla Humanities Journal asked me to jot down my thoughts on the teaching of the humanities and ideology, issues with which many in my generation have grappled. One would think that as I hear my eighties thumping nearer I would have some great insights that could be stated in a sentient lapidary tweet. Hasn't come to me yet.

Yet I could not pass up the request for purely personal reasons. I've watched, and even slightly helped, the National University of Kyiv-Mohyla Academy (NaUKMA) emerge from the complex meshing of the good that survived in the Soviet sphere and the best traditions of humanism that embered through people and ideas, despite ideological regimes. As always through history, humanism and ideology clashed with each other, taking on each other's coloring and making our life complex and interesting. Neither humanism, in its broadest definition, nor ideology, in its narrowest meaning, can be merely taught. Both need to resonate with their audience, not to mention adherents, to be understood and accepted.

During the existence of the USSR, Soviet Ukraine was more closed than Soviet Russia. More foreigners could visit Russia, while only a few were granted visas to Ukraine. It was particularly difficult for scholars of Ukrainian descent to get accepted on the exchange program, which was the only way to access any archives. I was already working on my third book in 1980 when I finally managed to get the necessary permissions to work in a few Ukrainian archives. As a first-time visitor to Kyiv, one Sunday I headed down to Podil to make a pilgrimage to what remained of Mohylianka (NaUKMA). I made it into the courtyard, peeked inside, and was unceremoniously thrown out for violating the privacy of the hospital wing of the buildings into which I wandered. I am certain the security officer knew very little about the history of the building he guarded so assiduously, but he certainly knew his regulations. Of course, at the time I could not even dream that a little more than a decade later the security officer would be taking care of the safety of a reborn Kyiv-Mohyla Academy, which resumed its original function of defining what it means to be human.

Big words are easy to define - until you see how people use them to characterize themselves and others. In the previous millennium humanity chiseled ideologies - integrated systems of belief or thought, which almost inevitably turned themselves inside out to destroy their makers. We, the educated elite who were formed by wars and by those who wrote about wars, sought hope in reason, in education, in what we call humanism to help us understand the potential of evil, of the danger lurking in any hermetically closed system of thinking, so we could save the world and avert more wars.

The generation of the First World War fought to end all wars. The Second World War idealists fought to destroy one totalitarian system, but failed to recognize the other. After the inevitable ideological wars, we turn to education, to the hopeful conviction that what we call 
goodness is both teachable and doable. We become complacent, self-satisfied that we have found the ideal balance between world and self, God-Goodness and Evil-Devil.

And then, inevitably we learn that our society, or some other society in our shared world chiseled a new hostile ideology, one that calls for action in the defense of a putative value that directly threatens us. Today we are shocked that amid poverty and hopelessness another closed system emerged to destroy its own followers by promising them a rich afterlife. We are confronted with an existential crossroads, the intersection of humanism and ideology, where each action inextricably has an ideological tinge. And then even the relatively well fed and the literate look for quick, almost magical solutions to the very problem of being human and wanting something better. In the midst of hopelessness, it is difficult to envisage the possibility of something better. Here is where radical ideologies step in. Simple solutions claim to solve the most complex issues in all radical ideologies.

Our American electoral procedure, long hailed as a paragon of practical democracy, is sinking into an unprecedented demagoguery because the line between conjecture and truth is as easily blurred with the help of modern technology as by the ravings of lunatics. Although history has taught us that wisdom is not necessarily guaranteed by the availability of knowledge, we nevertheless feel that surely a society that put a human on the moon can convince its citizens to sift chaff from wheat! Neither reticent Stalin, nor short high-pitched Hitler, nor chubby little Mussolini induced fear at the beginning of their careers.

Ukraine's rich history and its modern-day development prove that Ukraine is not a socalled "new country." There is no "Ukrainian Question," there is the state of Ukraine with a rich history of its people. But that same history volubly points out the repeated need for Ukraine to defend itself, frequently its very existence as a land with strong pervasive humanistic traditions. Today Ukraine again finds itself in a war not of its own making, a war where the need for action creates conditions that force clarity of definitions of extremely complex words and concepts. Yet if there is anything humanistic education has taught us it is the fluidity of concepts and the specificity of human actions. We write about big concepts, but the life we lead is both circumscribed by factors over which we have little control and expanded by how we position ourselves in our known universe. Even if your world ends with the square meters of your apartment and does not include the entry to the building, your life will be dependent upon others. You can be the best man imaginable in your little world but you will not have ensured the viability of your own home. Many tragic examples of your ancestors have proven the sad truth of this statement.

Let me illustrate by telling you about the life of Maria Rovenchuk-Labunka, a member of the Organization of Ukrainian Nationalists (OUN), which at the time she joined it, was largely a youth organization that helped mount guerilla warfare against both the German Nazis and the Soviet Communist forces. That struggle was suppressed only in 1952. The guerilla warfare was mainly done by the Ukrainian Insurgent Army, the UPA. It was a volunteer, self supporting force directed against the Germans and the Soviets, and was always on the lookout for enemy double agents in its ranks. The OUN was one of the founders of the UPA but the UPA is not the same as the original OUN. During the course of the warfare, the ideology of those who fought under the label of the Ukrainian Insurgent Army (UPA) morphed from the integral nationalism with fascist overtones of the OUN to an open social democratic platform that saw its final development as 
the human rights movement in the Soviet Gulags. The transformation of a part of the OUN is largely undocumented, except for a few original smuggled texts. In contrast, the founding OUN documents, most drafted by persons who themselves did not participate in the armed struggle, are widely available, even online.

Labunka, as a teenage girl in Ukrainian schools in Pechenizhyn, Kolomyia and later in Peremyshl, struggled to understand the major OUN texts and did not even bother much with its additional principles and recommendations of the OUN corpus. She disregarded much of the ideology that seemed irrelevant. There was work to be done and few opportunities for reflection. She simply worked for Ukraine whose land her parents still tilled, and that was enough ideology for her. She took for granted that for those who live in Ukraine, Ukraine is home. For this nationalist, all ethnicities who live in Ukraine were Ukrainian, even if they worshipped in different churches and spoke different languages.

There was always a lively and contentious discussion on the nature of the OUN and its relationship with the Ukrainian Insurgent Army, in which Labunka was among its first organizers and medics. Unlike the documented ideology, this type of activity has few sources. Labunka died in 1996 of cancer, a conventional middle-class housewife in northern Philadelphia, raising children, volunteer teaching in Saturday schools, and helping preserve the Plast scouting organization. She tried, through the years, to write down her experiences. Writing did not come easy.

Labunka struggled in writing her memoirs When the Forest Was Our Father not for lack of information or for having anything even remotely compromising to hide, but because she could not articulate the crisis of her life, the need to adjust the basics of her worldview. Her book, which appeared almost two decades after her death, will be filed under the neat labels of nationalism, guerrilla warfare, women in war, thus obscuring its true gist - balancing humanism and ideology. Labunka did not write specifically about that, although she very much lived that very tension.

Labunka's memoirs, although late in publication, are authentic. They reflect the teenage character of the first stages of the Ukrainian nationalist movement, its hesitant support by the war terrorized population that was not as keen to offer help as later accounts would have us believe, and the day-to-day tedium of war and occupations. The fullest part of the memoirs she was born in 1924 - cover her childhood, happy yet task-laden. Her education and her introduction to middle-class urban society receive a shorter treatment. Her long years in the Ukrainian underground between 1943 and 1948 are clear-headed and quickly covered. The book is frustratingly unfinished, very lightly edited, at times awkwardly unpolished and utterly fascinating.

It is fascinating because Labunka focuses on daily activities, on her feelings, on describing who else underwent the pitiful gatherings that were characterized as OUN trainings - the memorizing of the ideological texts, forced marches through difficult terrains, standing at attention at midday near water in the blazing sun and not drinking it. She frankly admits she did not quite get the ideology beyond the "fight for an independent Ukraine." She was an extremist nationalist, but she did not as a teenager fully comprehend the creed. She did not even know 
of the bloody rift in 1942 between the Melnyk and Bandera OUN factions. Can her actions be considered ideological?

A highly original segment of the work deals with her experience in one of the few successes of Ukrainians under German occupation between 1941-1944. The Nazis maintained that high school education is unnecessary for such agricultural under-races as Ukrainians, and most schools were closed. The fact that Ukrainians in Peremyshl managed to organize an academic live-in high school program for girls can be viewed as victory rather than some kind of collaboration. A diploma would serve to open doors for work or further study. Yet Labunka, upon completing the live-in program and passing the test, publicly rejected the document because one of her fellow students was denied it on the basis of not having an adequate identity card.

It made little difference in the short run. Labunka went underground and eventually did document in detail the difficulties of even daily living in the underground. Ukrainians have very few such documents, and Labunka's deserve to be mined by scholars and the recently minted public intellectuals who pontificate on ideology, history and choices made when there is no opportunity for choice.

Why did Labunka not complete her memoirs? Mrs. Labunka led a private life, very aware of the difficult fate of many of her surviving loved ones and friends who wound up in the USSR at the end of war. She was loathe to do anything that might be used by the Soviets against them. She knew many who died for the cause for which she fought. But she also realized that the vast majority of supporters of Ukraine's independence nevertheless had to find a way of accommodating themselves to the Soviet regime. She refrained from public statements that would make those persons lives even more difficult, and postponed publicizing her experiences, so that the memoirs remained unfinished. As many of her generation, her silence was a victim of the Soviet terror, although she lived her life in the USA. She wrote more about her family and their life than about her life underground. She wrote of the people with whom she shared the formative period of her life but not about the UPA ideology, since that ideology was sketchy to begin with. She wrote of her limitations and difficulties, of the colleagues who perished one way or another. She realized that her division of the world into the good "We" and the bad "They" was inadequate, but she could not put on paper where those thoughts led her. It is therefore both appropriate as well as ironic that her memoirs are introduced by the venerable ex-Soviet but unquestionably patriotic Ukrainian poet, Dmytro Pavlychko.

Yes, Maria Labunka was a genuine hero. Of course, she did not consider herself a hero; true heroes never do. She was one of the few who made the grueling clandestine two month forced journey in the summer of 1948 from the Carpathians to the Alps. The goal was to bring knowledge of the guerilla warfare to the West, to somehow gain support for those left back home who tried to continue to fight against the Soviets once the Nazis were defeated. Once in the West, she could not understand how her fellow Ukrainian refugees, mercifully housed in Displaced Persons Camps, could organize social dances, while she visualized the remaining guerillas in the winter woods. Labunka lived the ghastly deaths of so many of her friends who died not for the ideological trappings but for a Ukraine that was the ideal in their hearts. But she could not, like some other writers, gild her underground activity, nor give it much political 
meaning. But how could she question youthful total dedication to a cause that seemed to many at best a dream?

It so happened that Maria Rovenchuk-Labunka settled in Philadelphia and quietly raised a family where my family had also ended up after the War. I'm fifteen years Labunka's junior and I spent my teenage years arguing the limitations of political ideologies, including that of the OUN. My extended family was divided on that issue, so no great courage was needed for me to speak my youthful mind. Before World War II my father was among those lawyers who publicly defended members of the OUN before the law in Poland, while excoriating their elders in private for ruining young lives needlessly. But when the chips were down in his own youth, my father had gone to fight for Ukraine with his brothers in the aftermath of World War I. Their failure stimulated the establishment of the clandestine OUN with its terrorist arm and its various factions.

It was easy for me in the United States to see the limitations of ideological thinking of all stripes. I had the tools and the support, I had the time and inclination to study, the opportunity to argue, and the availability of other models.

I came to the USA when I was not yet 10, but I cannot say that I grew up in America. Rather along with my colleagues we came of age in the pleasant Ukrainian ghetto in Philadelphia. We lived our Ukrainian-American existence, which shifted focus to America only in college. Among our many youthful activities was an attempt to understand Ukrainian émigré political parties, since these parties did not engage in real political activity as we saw politics practiced in the States. A number of the political figures deigned to meet with us, teenagers, others did not. But our meetings caught the interest of Ukrainian émigré intellectuals, among them Ivan Lysiak-Rudnytsky. He was in his element — lecturing us, debating the political leaders, blending Ukraine with the world. Mrs. Labunka's story was at best whispered, and no one invited her to participate in these small matches of words.

Decades passed. The ghetto shrunk to a few churches. The Soviet Union was opening up and some of us felt that Ukrainian communists were both human and Ukrainian and it would be interesting to know what they were thinking. Perhaps our limited immigrant ghetto experience helped us to find common ground with the very few Ukrainians whom we could meet when they came to the States by the end of our "revolutionary" 1960 .

Intra-Ukrainian émigré debates continued, which had continued at a lower volume, now escalated. We became some sort of a new "crypto-Communist enemy" in the West, and at the same time, "the tails of rabid nationalist dogs" in the East.

One of the last emigré debate incidents in which I was involved, dealt with another UPA veteran, Marichka Savchyn-Pyskir. Her memoirs Thousands of Roads - came out in the 1980s without fanfare, as one of the volumes of UPA documents that a group UPA veterans and some scholars were publishing. Savchyn had worked with Labunka in the underground in the 1940s, but Savchyn was a city girl who married one of the underground leaders, had children, and continued to be a guerilla. The couple was caught in the mid-195os, and in a very complex maneuver Savchyn was sent by the Soviets to the States to act as an agent of the Soviet Secret Police. She was specifically instructed to work with the democratic wing of the OUN, which the Soviets could not penetrate. The couple had decided that once she was in the United States 
Savchyn was to defect, which she did, risking husband and child. But the OUN leadership in the USA doubted her, so she also, as Labunka, lived a quiet life. She married again and had two more children. When her book came out and her story became public there were those in the community who, as the OUN leadership, would not accept her story. They had a hard time crediting the Soviet regime with such intelligent game playing and they could not accept a female hero who lived a normal life.

Despite some murmurings, the venerable Ukrainian National Women's League of America duly honored Savchyn shortly after the original publication of her memoir.

Eventually, of course, the Ukrainian community in America recognized both women for their work and appropriately eulogized each of them upon their passing.

But their experiences, their assessment of their work and lives have not been incorporated into what is fashionably called the narrative of Ukraine. That was the narrative for the assertion of Ukraine's existence, theirs was the hidden underpinning of the humanity involved.

You, my Ukrainian readers, are on an accelerated life learning program — the continually shifting balance of priorities that make a full, worthwhile life. You have your own history with its rich values - where only you are able to learn what needs to be learned (to quote your great original Taras Shevchenko) and what needs to be unlearned. It is your life to build as best you can, not to emulate the past but to make the present and future suit your vision. That can be done only through the constant engagement with others, by continual study and action based on both study and engagement. A rally, a maidan, a living chain is fine, but you know better than I that they are symbols. The reality is you and the world in which you live.

The key to humanism is an old one, dangerously trite and yet still valid - "Life" has no answers, but we can influence its course if we understand who we are. A sense of self and of personal responsibility grounded in a conscience that accepts the innate value of others, even if you disagree with their values, can form the basis of a functioning society that could create conditions for a good life for most people. Naturally, there will be those who will argue that value lies in saving the core of the soul and knowledge should help find the soul. That journey may be easier in a group, but the prime responsibility remains individual and should be dealt with individually. As such, it does not fall in the purview of the present discussion of the public life.

You have a choice: You can help create a world in which the security person at Mohylianka knows her/his soul, or one where that person is only capable of enforcing memorized rules. But you do need that watchman. In that you have no choice. Because no society, as any of its members, is perfect.

\section{The Books}

Labunka, Maria (Iryna). Koly lis buv nash batko: Spomyny [When the Forest Was Our Father: Memoirs]. Kyiv: Osnovy, 2015.

Savchyn, Maria (Marichka). Tysiacha dorih: Spohady [Thousands of Roads: Memoirs]. Litopys Ukrainskoi Povstanskoi Armii, t.28, 1995. 


\section{讨}

Martha Bohachevsky-Chomiak, a Phi Beta Kappa graduate of the University of Pennsylvania, holds an MA, PhD and Russian Institute Certificate from Columbia University, and has been the recipient of many grants and awards. She published a number of books on key issues in Russian and Ukrainian history, and is best known for her trailblazing study of women in Ukraine, Feminists Despite Themselves. She has taught at Manhattanville College and Johns Hopkins, George Washington, Catholic and Harvard universities, as well as at Kyiv National University, the National University of Kyiv-Mohyla Academy, and the Ukrainian Catholic University, from which she holds an honorary doctorate. In retirement, she is completing a book on the consolidation of the Ukrainian Catholic Church in the United States. She was married for more than 5 o years to the late Ross L. Chomiak, a journalist, and has two daughters and four grandchildren.

\section{Appendix}

By Maik Yohansen (1895-1937)

Vy, shcho ne znaiuchy mety

Spynialy vtomleni zdorovoho, Lezhit sobi - do neba yty

Shche dovho.

I vy, shcho do nebes mosty

Svoieiu okropyly kroviu

Prostit vy nam. Idemo. Yty

Shche dovho.

I piiut pivni na puty,

I klychut vikovichnym zovom.

Zabuly vse. Idemo. Yty

Shche dovho.
You clueless of the goal

Wiped out and blocking others

Sleep on - heaven's still

far, far away.

And you, whose blood washed heaven's bridges, Forgive us. We're on our way.

For we've yet far to go.

Cocks crow along the way

In their eternal tone.

Forgetting all, on we go. We've

yet so far to go. 